PRZEGLĄD NAUK HISTORYCZNYCH 2016, R. XV, NR 2

http://dx.doi.org/10.18778/1644-857X.15.02.07

Mazgorzata PrzeniosŁo

Uniwersytet Jana Kochanowskiego w Kielcach ${ }^{*}$

\title{
Szkoły matematyczne w międzywojennej Polsce i ich związki z nauką światową
}

Streszczenie. W okresie międzywojennym polscy matematycy stworzyli dwie prężne szkoły matematyczne - w Warszawie i we Lwowie. W Warszawie twórcami byli: Wacław Sierpiński, Zygmunt Janiszewski, Stefan Mazurkiewicz, a we Lwowie - Hugo Steinhaus i Stefan Banach. Mimo nieistnienia przez wiele lat państwa polskiego i związanych $z$ tym niekorzystnych warunków do rozwoju rodzimej nauki obie szkoły szybko zanotowały znaczące osiągnięcia. Źródłem tego sukcesu było zarówno wpisanie się szkół w nowe trendy w uprawianiu matematyki i założenie odpowiadających im specjalistycznych czasopism - „Fundamenta Mathematicae” oraz „Studia Mathematica”, jak i mnogość zagranicznych podróży naukowych. Oba czasopisma odniosły międzynarodowy sukces i szybko zostały uznane przez obcokrajowców jako odpowiednie forum do prezentacji własnych badań. "Fundamenta Mathematicae" stały się jednym $z$ najważniejszych na świecie periodyków poświęconych teorii mnogości, „Studia Mathematica” - analizie funkcjonalnej. Czasopisma budowały renomę polskiej szkoły matematycznej, a wraz $z$ jej wzrostem coraz więcej jej przedstawicieli było zapraszanych przez zagraniczne ośrodki naukowe, zarówno na krótkie pobyty, jak i całe cykle wykładów. Coraz więcej zagranicznych uczonych, zarówno znanych profesorów, jak i stypendystów, przyjeżdżało też do Warszawy i Lwowa, by współpracować $z$ tamtejszymi matematykami, wygłaszać wykłady czy uczestniczyć w konferencjach.

Słowa kluczowe: historia nauki w II Rzeczypospolitej, matematycy, szkoły matematyczne.

W

dwudziestoleciu międzywojennym polska matematyka zdobyła światowe uznanie, którego nie miała nigdy wcześniej. Stało się to głównie za sprawą dwóch szkół nauko-

* Wydział Pedagogiczny i Artystyczny, Instytut Edukacji Szkolnej, Zakład Podstaw Dydaktyki. 
wych powstałych w Warszawie i we Lwowie wkrótce po odzyskaniu niepodległości. Zostały one stworzone przez wielkie osobowości polskiej matematyki, w Warszawie - Wacława Sierpińskiego ${ }^{1}$, Zygmunta Janiszewskiego $^{2}$ i Stefana Mazurkiewicza ${ }^{3}$, a we Lwowie - Hugona Steinhausa ${ }^{4}$ i Stefana Banacha ${ }^{5}$. W pozostałych ośrodkach akademickich międzywojennej Polski szkoły matematyczne nie powstały, ale i tam pracowali znani w świecie naukowcy. Szkoły warszawska i lwowska niezwykle szybko odniosły sukces mimo wcześniejszego wieloletniego braku polskiej państwowości i związanych z tym niesprzyjających warunków dla rozwoju rodzimej nauki. Nasuwa się więc pytanie o źródła tego fenomenu. W tekście tym chciano przeanalizować zarówno mechanizmy związane $z$ tworzeniem szkól, jak i z budowaniem ich pozycji w świecie matematycznym. W tym drugim wypadku skoncentrowano się na roli specjalistycznych czasopism matematycznych o charakterze międzynarodowym powstałych w Warszawie i we Lwowie w okresie międzywojennym oraz na rozwoju zagranicznych kontaktów naukowych polskich matematyków. Ważnym problemem badawczym był też trwały wkład obu szkół w naukę światową.

Przełom XIX i XX w. przyniósł znaczne zmiany w podejściu do prowadzenia badań w matematyce. Nadano już wówczas współczesny kształt podstawom klasycznych jej działów, którymi od lat zajmowano się w europejskich ośrodkach naukowych. Powstała więc potrzeba poszukiwania nowych pół badawczych, zaczęto tworzyć nowe dziedziny matematyki. Działo się w niej tak wiele, jak nigdy

${ }^{1}$ Wacław Franciszek Sierpiński (1882-1969), absolwent Cesarskiego Uniwersytetu Warszawskiego, kandydat nauk w 1904 r., doktorat na Uniwersytecie Jagiellońskim [dalej: UJ] w 1906 r., studia uzupełniające w Getyndze, habilitacja na Uniwersytecie we Lwowie [dalej: UL] w 1908 r., od 1910 r. profesor nadzwyczajny tej uczelni, od 1919 r. profesor zwyczajny Uniwersytetu Warszawskiego [dalej: UW].

${ }^{2}$ Zygmunt Janiszewski (1888-1920), studia w Zurychu, Getyndze, Monachium i Paryżu, doktorat na Sorbonie w 1911 r., habilitacja w 1913 r. na UL, od 1919 r. profesor nadzwyczajny UW.

${ }^{3}$ Stefan Mazurkiewicz (1888-1945), studia w Krakowie, Monachium, Getyndze i Lwowie, doktorat na UL w 1913 r., habilitacja na UJ w 1919 r., od tego roku profesor nadzwyczajny UW, od 1920 r. zwyczajny.

${ }^{4}$ Hugo Dionizy Steinhaus (1887-1972), absolwent Uniwersytetu w Getyndze, tam doktorat w 1911 r., habilitacja w 1917 r. na UL, od 1920 r. profesor nadzwyczajny tej uczelni, wówczas Uniwersytetu Jana Kazimierza [dalej: UJK], od 1923 r. zwyczajny.

5 Stefan Banach (1892-1945), studia w Szkole Politechnicznej we Lwowie, doktorat na UJK w 1920 r., habilitacja w 1922 r. i od tego roku profesor nadzwyczajny tej uczelni, od 1927 r. zwyczajny. 
wcześniej, stawała się ona coraz obszerniejsza, co u wielu wzbudzało obawy, że nikt nie będzie w stanie jej objąć - do tej pory matematycy zazwyczaj zajmowali się bowiem cała dyscypliną. Zapowiadało to rychłe nadejście czasów ścisłej specjalizacji w uprawianiu różnych dziedzin matematyki. Ich zwiastunem był słynny wykład Davida Hilberta przedstawiony w 1900 r. na II Międzynarodowym Kongresie Matematycznym w Paryżu, który zawierał 23 problemy pokazujące wielość pól badawczych w matematyce. W tym czasie następowała też zmiana w podejściu do organizowania pracy naukowej. Zaczęto dostrzegać, że zakładanie szkół naukowych (rozumianych jako grupy osób współpracujących ze sobą na polu naukowym związanych $z$ tym samym ośrodkiem) zwykle daje znacznie większe możliwości rozwoju i prezentacji osiagnięć niż ograniczanie się do indywidualnej pracy uczonych ${ }^{6}$.

Nowe trendy w uprawianiu matematyki były już wówczas widoczne w kilku europejskich ośrodkach naukowych, szczególnie w Getyndze i Paryżu. Getynge powszechnie w tym czasie uznawano za najprężniejszy ośrodek matematyczny Europy. Szkoła stworzona na tamtejszym uniwersytecie przez Feliksa Kleina i Davida Hilberta składała się $z$ wielkich pasjonatów matematyki, najbardziej znani spośród nich to: Ernst Zermelo, Hermann Minkowski, Constantin Carathéodory, Edmund Landau oraz Gustav Hergoltz. Słynęła $z$ partnerstwa i współpracy również $z$ najmłodszymi adeptami tej dyscypliny. W zasadzie każdy czynny naukowo matematyk miał wówczas w planach odwiedzenie Getyngi, szczególnie chętnie ściagali tam utalentowani młodzi naukowcy $z$ całej Europy. Podobnie większość matematyków postrzegała Paryż i tamtejszą szkołę matematyczna $z$ wielkimi osobowościami wciąż czynnymi naukowo - Henrim Poincaré i Emilem Picardem, a wówczas współtworzoną także m.in. przez Henriego Lebesgue'a, Jacques'a Hadamarda, Paula Montela, Emila Borela oraz Maurica Frécheta. Równie często też Paryż odwiedzała. Matematycy chętnie umieszczali także swoje teksty w znanym paryskim czasopiśmie Francuskiej Akademii Nauk - „Comptes Rendus de l'Académie des Sciences”. W periodyku opublikowano też wiele prac zdolnych początkujących matematyków, również polskich. Jego redakcja była znana $z$ przychylności dla młodych talentów. W Getyndze i Paryżu przed 1918 r. przebywało kilkunastu przyszłych profesorów matematyki polskich uczelni,

${ }^{6}$ C. Reid, Hilbert, New York 1970, s. 65-83; M. Kordos, Wykłady z historii matematyki, Warszawa 2010, s. 191-243, 253-273. 
m.in. niemal wszyscy $z$ wymienionych późniejszych twórców sukcesu polskich szkół matematycznych ${ }^{7}$.

$\mathrm{Na}$ początku XX w., mimo braku państwa polskiego, funkcjonowały polskie uczelnie, ale dotyczyło to tylko zaboru austriackiego. Począwszy od lat sześćdziesiątych XIX w., wraz ze zmianami, które następowały w państwie Habsburgów, miała bowiem miejsce stopniowa repolonizacja Uniwersytetu Jagiellońskiego w Krakowie i Uniwersytetu we Lwowie oraz Politechniki w drugim $z$ wymienionych ośrodków. Już na początku XX w. w Krakowie i we Lwowie można było znaleźć zarówno wybitnych profesorów matematyki, jak i utalentowanych młodych adeptów tej dyscypliny. Wielu $z$ nich poznało zagraniczne szkoły naukowe w czasie licznych podróży, miało więc możliwość przeniesienia na polskie uczelnie zdobytych tam doświadczeń. Mimo to na rodzimym gruncie takie szkoły nie powstawały. Współpraca $z$ zagranicznymi szkołami matematycznymi i istnienie polskich uczelni nie wystarczały, by pracujaccy na nich matematycy stworzyli własna szkołę. Nawet mająca takie doświadczenie znaczaca osobowość naukowa nie dawała gwarancji jej powstania. Taka osoba był chociażby Stanisław Zaremba, który ponad 10 lat spędził w Paryżu, a potem przez wiele lat zajmował katedrę profesorska na UJ, był nieprzeciętnym naukowcem, ale szkoły nie stworzył, również wtedy, gdy takowe powstały w Warszawie i we Lwowie ${ }^{8}$. Oprócz możliwości matematycznych konieczne były bowiem zdolności organizacyjne i umiejętność dostrzeżenia potrzeby zmian w podejściu do aranżowania pracy naukowej.

Wymienione cechy niewątpliwie miał wspominany Wacław Sierpiński. Konfrontując obserwacje polskiego środowiska matematycznego $z$ doświadczeniami zdobytymi podczas pobytu w Getyndze, doszedł on do przekonania, że największa przeszkodę w rozwoju rodzimej matematyki stanowi brak zespołów osób o podobnych zainteresowaniach pracujacych wspólnie w tym samym miejscu ${ }^{9}$. Jako profesor Uniwersytetu we Lwowie podją starania, by stworzyć taką grupę naukowców. W 1913 r. ściagnął do Lwowa młodego

${ }^{7}$ C. Reid, op. cit., s. 84-110; M. Przeniosło, Matematycy polscy $w$ okresie międzywojennym, Kielce 2011, s. 32, 33.

${ }_{8}$ Teczka osobowa S. Zaremby, Archiwum Uniwersytetu Jagiellońskiego, Senat Akademicki II, sygn. 619; K. Stopka, A.K. Banach, J. Dybiec, The history of the Jagiellonian University, Kraków 2000, s. 184.

${ }^{9}$ W. Sierpiński, O polskiej szkole matematycznej, „Problemy” 1963, t. III, s. $147-149$. 
absolwenta Sorbony - dr. Zygmunta Janiszewskiego ${ }^{10}$. Powiększał też grupę współpracowników, wyszukując utalentowanych uczniów. W 1913 r. na UL dwóch jego wychowanków otrzymało stopień doktora - Stefan Mazurkiewicz ${ }^{11}$ i Stanisław Ruziewicz ${ }^{12}$. Wybuch wojny przerwał współprace grupy, jednak idea tworzenia szkół naukowych przetrwała.

W kolejnych latach pomysł ten najbardziej zdecydowanie propagował Zygmunt Janiszewski. Po pobycie w wojsku (w sierpniu 1914 r. zaciągnął się do Legionów Polskich) wrócił w 1916 r. na Uniwersytet we Lwowie ${ }^{13}$. Szansę na rozpowszechnianie idei tworzenia szkół naukowych dała mu wówczas ankieta ${ }^{14}$ rozesłana przez Kasę im. Mianowskiego polskim uczonym różnych dyscyplin z prośba o przekazanie informacji dotyczacych potrzeb polskiej nauki. W odpowiedzi na nia Janiszewski napisał tekst O potrzebach matematyki $w$ Polsce, który stał się potem "programem ideowym” całego międzywojennego pokolenia polskich matematyków, bezsprzecznie przyczynił się też do powstania prężnych szkół naukowych w Warszawie i we Lwowie. Ukazał się on w 1918 r. w pierwszym tomie wydawanego przez Kasę nowego czasopisma „Nauka Polska” poświęconego rozwojowi nauki. Janiszewski dokonał w nim bardzo wnikliwej oceny kondycji ówczesnej polskiej matematyki, $z$ rozpoznaniem przyczyn trudnej sytuacji i wskazaniem środków zaradczych. Najbardziej cenne uwagi poczynił na temat systemu publikacji. Zwracał uwage na rozproszenie prac naukowych w różnych czasopismach $\mathrm{w}$ wielu krajach, co utrudniało - jego zdaniem - upowszechnienie w świecie polskiej myśli matematycznej. Wskazywał na potrzebę zakładania w Polsce czasopism matematycznych o waskiej specjalizacji wydawanych w językach uznanych w tej dyscyplinie za międzynarodowe (angielski, francuski, niemiecki i włoski), apelował: "chcac zdobyć sobie odpowiednie stanowisko w świecie naukowym, przyjdźmy z własną inicjatywą". Sądził, że każde $z$ takich czasopism dałoby polskim matematykom duże możliwości ogłaszania

${ }^{10}$ Akta Z. Janiszewskiego, Archiwum Główne Akt Dawnych, C.K. Ministerstwo Wyznań i Oświaty, sygn. 119u.

${ }_{11}$ Teczka osobowa S. Mazurkiewicza, Archiwum Akt Nowych [dalej: AAN], Ministerstwo Wyznań Religijnych i Oświecenia Publicznego [dalej: MWRiOP], sygn. 4318, k. 75.

${ }^{12}$ Teczka osobowa S. Ruziewicza, AAN, MWRiOP, sygn. 5435, k. 98.

13 Teczka osobowa Z. Janiszewskiego, Lwowskie Państwowe Archiwum Obwodowe we Lwowie [dalej: LPAO], UJK, f. 26, op. 5, spr. 2242, k. 45.

${ }^{14}$ Od Redakcji, „Nauka Polska” 1918, t. I, s. 8. 
własnych wyników i docierania $z$ nimi do specjalistów. Umożliwiłoby także osobiste kontakty $z$ uczonymi zagranicznymi, pisał: „bylibyśmy wtedy ośrodkiem technicznym publikacji matematycznych $\mathrm{w}$ tej gałęzi. Do nas przysyłanoby rękopisy nowych prac i utrzymywanoby $z$ nami stosunki". To $z$ konsolidacja polskich naukowców zajmujących się właśnie tym działem matematyki w ośrodku wydającym dane czasopismo dałoby - jego zdaniem - szansę na powstanie szkoły ${ }^{15}$. Pomysł specjalizacji czasopism był nowatorski, wychodzace w tym czasie w świecie periodyki były poświęcone całej matematyce. Janiszewski ideę wąskiej specjalizacji czasopism propagował już wcześniej, w 1912 r., podzielił się nią $z$ jednym $z$ najbardziej znanych francuskich matematyków Emilem Borelem. Ten odniósł się do niej krytycznie, był zwolennikiem dotychczasowego systemu - czasopism poświęconych całej matematyce. Janiszewski, jak się później okazało, nie zarzucił swojego pomysłu, a i inni uczeni doszli do podobnych wniosków ${ }^{16}$.

Wkrótce po powrocie Janiszewskiego na Uniwersytet pojawił się tam, w związku $z$ habilitacja, jego znajomy $z$ Legionów Polskich - Hugo Steinhaus. Janiszewski znalazł w nim wielkiego zwolennika, a potem także propagatora, swoich pomysłów, co w późniejszym okresie zdecydowało o sukcesie międzywojennej polskiej szkoły matematycznej ${ }^{17}$. Takie znaczenie miało też inne zdarzenie sprzed 1918 r. związane $z$ osobą Steinhausa. W lipcu 1916 r., po pobycie w wojsku, zamieszkał on w Krakowie. Jak wspomina, spacerując letnim wieczorem po jednym $z$ miejskich parków tzw. Plantach, usłyszał słowa bliskie jego zainteresowaniom - „miara Lebesgue'a”, a że był człowiekiem bardzo otwartym w kontaktach $z$ innymi, podszedł do dwóch młodych ludzi rozmawiających na ten temat i się przedstawił. W ten sposób poznał Stefana Banacha, najwybitniejszego, jak się później okazało, $z$ międzywojennych polskich matematyków ${ }^{18}$. Steinhaus często potem mawiał, że Banach był „największym odkryciem” jego życia ${ }^{19}$.

Możliwości realizacji idei tworzenia szkół matematycznych i specjalizacji czasopism pojawiły się już na początku 1918 r. Wiosną tego

${ }^{15}$ Z. Janiszews ki, O potrzebach matematyki $w$ Polsce, ibidem, s. 14-16.

${ }^{16}$ K. Ku ra tow ski, Notatki do autobiografii, Warszawa 1981, s. 72.

${ }^{17}$ H. Stein haus, Wspomnienia i zapiski, Wrocław 2002, s. 92, 98; Listy Zygmunta Janiszewskiego, oprac. S. Kolankowski, Warszawa 1980, s. 45.

${ }^{18} \mathrm{H}$. Stein haus, Wspomnienia i zapiski..., s. 97, 98.

${ }^{19}$ R. Kałuża, Stefan Banach, Warszawa 1992, s. 71. 
roku Janiszewskiemu zaproponowano pracę na reaktywowanym w 1915 r. Uniwersytecie Warszawskim, gdzie wcześniej zatrudniono Stefana Mazurkiewicza i zaproszono Wacława Sierpińskiego ${ }^{20}$. Janiszewski wkrótce po podjęciu tam pracy rozpoczał wdrażanie w życie pomysłu związanego $z$ założeniem nowego periodyku. Poszukując jego profilu, zaproponował równie oryginalne rozwiąanie, jak specjalizacja czasopism. Jak wspomina Hugo Steinhaus, Janiszewski zwracał uwage na to, że polska matematyka jest zbyt „zapóźniona” w stosunku do innych państw, by szybko mogła odnosić sukcesy w matematyce klasycznej. Sądził jednak, że w kraju wystarczająco duża grupa uczonych zajmuje się podstawami matematyki i przede wszystkim nowo tworzącą się i wciąż niedoceniana teorią mnogości. Uważał, że początkowy etap rozwoju teorii mnogości stwarza szansę na jej budowanie niemal od podstaw przez polskich matematyków i na to, że będzie ona kojarzona w świecie właśnie $z$ grupa Polaków pracujacych w Warszawie ${ }^{21}$. Swoje czasopismo Janiszewski nazwał „Fundamenta Mathematicae”. Miało być ono poświęcone teorii mnogości i działom pokrewnym - m.in. topologii i analizie funkcjonalnej22. Realizując $z$ kolei ideę tworzenia szkół matematycznych, Janiszewski i Mazurkiewicz szybko skupili wokół siebie kilkuosobowa grupa młodych matematyków piszących pod ich kierunkiem prace doktorskie $z$ topologii, która obaj zajmowali się naukowo. Zorganizowali pierwsze $\mathrm{w}$ świecie seminarium o takiej specjalizacji ${ }^{23}$.

Niemal od początku do grupy warszawskiej należeli: Kazimierz Kuratowski, Stanisław Saks, Bronisław Knaster, Antoni Zygmund, Stefan Straszewicz, Aleksander Rajchman, Zygmunt Zalcwasser, a $z$ najmłodszych (urodzonych po 1900 r.): Kazimierz Zarankiewicz, Karol Borsuk, Edward Szpilrajn (Edward Marczewski - takie nazwisko przyją w czasie II wojny światowej), Stefania Braun, Zenon Waraszkiewicz, Samuel Eilenberg oraz dwaj logicy zajmujący się również teorią mnogości Alfred Tarski i Adolf Lindenbaum. $Z$ grupa współpracowali także Otton i Stanisława Nikodym z Krakowa (na początku lat trzydziestych zamieszkali na stałe w Warszawie).

${ }^{20}$ Nowi profesorowie Uniwersytetu Warszawskiego, „Głos Narodu”, 31 X 1918, nr 245, s. 2; Listy Zygmunta Janiszewskiego..., s. 16.

${ }^{21} \mathrm{H}$. Stein hau s, Między duchem a materia pośredniczy matematyka, oprac. J. Łukaszewicz, Warszawa 2000, s. 108, 109.

${ }^{22}$ Szerzej na temat „Fundamenta Mathematicae” por. M. Przeniosło, International mathematical journals published in Poland between the Wars, „British Society for the History of Mathematics Bulletin" 2009, t. XXIV, s. 20-26.

${ }^{23}$ K. Kuratowski, Notatki do autobiografii..., s. 61, 78. 
We Lwowie wyjazd dwóch najprężniejszych matematyków - Wacława Sierpińskiego i Zygmunta Janiszewskiego - nie spowodował stagnacji w rozwoju tamtejszego środowiska matematycznego. W 1920 r. katedrę profesorska powierzono tam Hugonowi Steinhausowi ${ }^{24}$. Dobra opinia, która Steinhaus zdobył w środowisku lwowskim, nie tylko jemu dała szansę na karierę naukową: wkrótce ściagnął bowiem do Lwowa Stefana Banacha. Dzięki jego wstawiennictwu Banach został asystentem na tamtejszej Politechnice w katedrze zajmowanej przez prof. Antoniego Łomnickiego. Przyjęcie na asystenturę nie było proste, ponieważ Banach ukończył tylko dwa lata studiów (w 1914 r. zdobył na PLw tzw. półdyplom) i aktualnie nie studiował. Jeszcze w 1920 r. Banach złożył pracę doktorska na Uniwersytecie ${ }^{25}$.

Rok 1920 oprócz pomyślnych dla rozwoju matematyki wydarzeń we Lwowie przyniósł też zdarzenie niewątpliwie dla niej niekorzystne. W styczniu tego roku zmarł niespodziewanie Zygmunt Janiszewski, mając zaledwie 33 lata. Praca związana $z$ wypromowaniem doktorantów pracujących pod jego kierunkiem i wydaniem pierwszego tomu „Fundamenta Mathematicae” została dokończona przez Wacława Sierpińskiego i Stefana Mazurkiewicza. Pod ich redakcją czasopismo odniosło międzynarodowy sukces. Szybko zostało uznane przez obcokrajowców za odpowiednie forum do prezentacji własnych badań. Stało się jednym $z$ najważniejszych na świecie periodyków poświęconych teorii mnogości, która była domeną Sierpińskiego, i działom pokrewnym. Niewattpliwie upowszechniało prace polskich matematyków, dzięki czemu budowało pozycję zarówno szkoły warszawskiej, jak i lwowskiej, bo i tam uprawiano dziedziny leżące w kręgu zainteresowań czasopisma.

W zwiąku $z$ taka rola warszawskiego periodyku istotne jest ustalenie, w jaki sposób obcokrajowcy poznawali nowe czasopismo, dlaczego zaczynali do niego pisywać i jak zyskało ono renomę. W przypadku pierwszych tomów wielu matematyków $z$ całego swiata prawdopodobnie otrzymało czy to cały tom periodyku, czy poszczególne artykuły opublikowane w „Fundamenta Mathematicae" od redakcji lub autorów. Był to bowiem szeroko propagowany przez Sierpińskiego sposób upowszechniania własnych prac. Takie promowanie czasopisma sugeruje także to, że jego pojawienie się

${ }^{24}$ Teczka osobowa H. Steinhausa, LPAO, UJK, f. 26, op. 5, spr. 2162, k. 77, 111.

${ }^{25}$ H. Stein haus, Wspomnienia i zapiski..., s. 46, 55, 102; K. Twardows ki, Dzienniki, t. II, Toruń 1997, s. 62, 64, 106, 140. 
odbiło się szerokim echem w świecie matematycznym. Życzliwa ocena nowego periodyku znalazła się w 1921 r. w znanym „American Mathematical Monthly". Raymond C. Archibald podkreślał, że "Fundamenta Mathematicae" to najważniejsze $z$ czasopism, które pojawiły się w ciagu ostatnich kilku lat ${ }^{26}$. Po ukazaniu się tomu drugiego francuski matematyk Henry Lebesgue napisał dość obszerny artykuł do równie znanego periodyku „Biulletin des Sciences Mathématiques", w którym przedstawiał nowe czasopismo, chwalił pomysł jego założenia, siłę twórczą polskich matematyków zajmujących się teorią mnogości, ich odwagę i determinację w rozwijaniu tej dotychczas niedocenianej dziedziny matematyki ${ }^{27}$. W liście do Wacława Sierpińskiego wyrażał też jednak wątpliwość, czy redakcja tak wyspecjalizowanego czasopisma będzie w stanie pozyskiwać dostatecznie dużo nowych tekstów, aby kontynuować wydawanie, nie obniżając poziomu ${ }^{28}$. W kolejnych latach pozostał życzliwym krytykiem i propagatorem „Fundamenta Mathematicae”, napisal do niego cztery prace. Zapewne artykuły prezentujące warszawski periodyk przysporzyły mu nowych czytelników i autorów. W 1924 r., po wydrukowaniu pięciu numerów czasopisma, Wacław Sierpiński otrzymał list od znanego niemieckiego matematyka Feliksa Hausdorfa, w którym ten „zachwyca się 'Fundamentami' i pisze, że wyniki zawarte w 'Fundamentach' uwzględni obszernie w nowym wydaniu swojej Teorii mnogości, które szykuje do druku"29. W następnym tomie warszawskiego periodyku Hausdorff opublikował też swój artykul, a potem jeszcze siedem innych.

Oprócz najbardziej znanych matematyków zapewne ci zaprzyjaźnieni $z$ Wacławem Sierpińskim również otrzymali od niego pierwsze tomy „Fundamenta Mathematicae”. Tak było prawdopodobnie $z$ rosyjskim uczonym Nikołajem N. Łuzinem, który szybko poznał nowe czasopismo i zaczął do niego pisywać. Niewątpliwie należał on do grona bliskich znajomych Sierpińskiego z czasów jego przymusowego pobytu w Moskwie w latach 1915-1918 (został internowany przez Rosjan po wybuchu I wojny światowej). Kilku uczniów

${ }^{26}$ R.C. Archibald, Notes, „American Mathematical Monthly” 1921, t. XXVIII, s. 317 .

${ }^{27} \mathrm{H}$. Lebesgue, A propos d'une nouvelle revue mathematique: 'Fundamenta Mathematicae', „Biulletin des Sciences Mathématiques” 1922, t. XLVI, s. 35-48.

${ }^{28}$ Listy Wacława Sierpińskiego do Stanisława Ruziewicza, oprac. W. Więsław, „Wiadomości Matematyczne” 2004, t. XL, s. 145.

${ }^{29}$ Ibidem, s. 152. 
i współpracowników Łuzina też zostało autorami publikacji w warszawskim periodyku. Duże zainteresowanie Rosjan czasopismem było zapewne także wynikiem dostępności polskich periodyków matematycznych w ZSRR w okresie izolacji tamtejszej nauki na poczatku lat dwudziestych. Powodowała ona sytuację, że rosyjscy matematycy mieli spore kłopoty ze śledzeniem nowych badań prowadzonych na świecie i $z$ uniknięciem powielania odkrytych już faktów. Dla wielu $z$ nich „Fundamenta Mathematicae” były - jak to określił Kazimierz Kuratowski - jedynym oknem na świat ${ }^{30}$.

Za sprawą kontaktów osobistych pojawiła się w „Fundamenta Mathematicae" także duża grupa autorów z USA. Na przykład Gordon T. Whyburn, który spośród wszystkich uczonych zagranicznych opublikował najwięcej artykułów (16). Bez wątpienia zainteresował się czasopismem dzięki współpracy z Kazimierzem Kuratowskim, podobnie było w przypadku Williama L. Ayresa (wydrukował siedem prac). Obaj amerykańscy matematycy przyjeżdżali do Polski, by $z$ nim pracować. Za sprawą Kuratowskiego warszawski periodyk zyskał i innych amerykańskich autorów. W 1936 r. Kuratowski przebywał bowiem w USA i Kanadzie, gdzie wygłosił cykl wykładów ${ }^{31}$ na zaproszenie kilkunastu uniwersytetów. W czasie wykładów mówił też o „Fundamenta Mathematicae”32.

Kolejnym ważnym powodem podejmowania współpracy $z$ „Fudamenta Mathematicae" była chęć odniesienia się do wyników zawartych w przeczytanych tekstach zamieszczonych w wydanych tomach czasopisma. Duża część artykułów autorstwa matematyków $z$ wielu różnych państw miała bowiem charakter uzupełniający lub polemiczny w stosunku do prac tam opublikowanych. „Fundamenta Mathematicae” były więc czytane przez specjalistów $z$ całego świata. Wniosek ten można również potwierdzić, biorąc pod uwagę stale rosnacy zakres wymiany poszczególnych tomów z redakcjami innych czasopism. Informowano o nim w poszczególnych tomach periodyku. W numerze 15 (1930 r.) można np. znaleźć 88 pozycji

${ }^{30}$ K. Kuratowski, Pół wieku matematyki polskiej 1920-1970. Wspomnienia i relacje, Warszawa 1973, s. 70. Szerzej na temat współpracy matematyków z obu państw por. M. Przeni o sło, Kontakty naukowe polskich i rosyjskich matematyków $w$ dwudziestoleciu międzywojennym, „Studia z Dziejów Rosji i Europy Środkowo-Wschodniej” 2014, t. XLIX, s. 115-129.

${ }^{31}$ Szersze rozważania na temat naukowych podróży zagranicznych polskich matematyków i ich wpływu na rozwój rodzimych szkół matematycznych zamieszczono w dalszej części tekstu.

${ }^{32}$ Teczka osobowa K. Kuratowskiego, AAN, MWRiOP, sygn. 3841, k. 236. 
(75 zagranicznych z 21 krajów i 13 polskich), w tomie 30 (1938 r.) - 110 tytułów (100 zagranicznych z 23 państw i 10 polskich). O dużej popularności czasopisma świadczy też przytoczona przez Wacława Sierpińskiego opinia Raymonda C. Archibalda, profesora Brown University w Providence, kierownika jednej z największych amerykańskich bibliotek, który w liście do Sierpińskiego stwierdził, że „Fundamenta Mathematicae” to w tej bibliotece najbardziej poczytne wydawnictwo ${ }^{33}$.

W 1935 r. opublikowano numer jubileuszowy „Fundamenta Mathematicae" - 25 - w podwójnej objętości. Ukazały się w nim prace wielu znanych matematyków $z$ całego świata zaproszonych przez redaktorów. $Z$ okazji tej rocznicy redakcja otrzymała też liczne gratulacje. W 1936 r. Jacob D. Tamarkin, profesor Uniwersytetu w Providence, opublikował bardzo pochlebny tekst majacy uczcić ukazanie się 25 tomów warszawskiego periodyku. Napisał w nim m.in., że pod mistrzowskim kierownictwem „Fundamenta Mathematicae" szybko stały się niezwykłym czasopismem cieszacym się międzynarodowym uznaniem, którego historia jest też historią rozwoju nowoczesnej teorii funkcji i teorii zbiorów ${ }^{34}$.

W latach 1920-1939 wydrukowano 32 tomy „Fundamenta Mathematicae”. Opublikowano w nich 934 artykuły naukowe autorstwa 212 matematyków pracujacych w 19 krajach, w tym 63 Polaków i 148 osób z zagranicy, najwięcej ze Stanów Zjednoczonych - 44 i ZSRR - 30. Wśród zagranicznych autorów największej liczby tekstów znaleźli się: Gordon T. Whyburn - USA (16), Maurice Fréchet - Francja (10) i Nikołaj N. Łuzin - ZSRR (9).

W rozwoju „Fundamenta Mathematicae” i warszawskiej szkoły matematycznej szczególną rolę odgrywał Wacław Sierpiński. Wkładał on wiele wysiłku w prace redakcyjne i naukowe zwiazane $z$ wydawaniem periodyku. Jego wyjątkowa pracowitość i opiekuńczość dostrzegali nawet zagraniczni naukowcy przyjeżdżajacy do Polski. Nikołaj N. Łuzin, po odwiedzinach w Warszawie w 1926 r., w liście do francuskiego matematyka Arnauda Denjoy wskazywał np. na osobowość Sierpińskiego jako jedna $z$ głównych przyczyn sukcesu warszawskiej szkoły matematycznej. Pisał o nim: „Pan Sierpiński jest znakomitym opiekunem naukowym. Stale pozostaje

${ }^{33}$ W. Sierpiński, Matematyka polska $w$ czasie wojny i po wojnie, „Nauka Polska” 1947, t. XV, s. 90.

${ }^{34}$ J.D. Tam arkin, 25 volumes of 'Fundamenta Mathematicae', „Bulletin of the American Mathematical Society” 1936, t. XLII, s. 300. 
w ścisłym kontakcie ze swoimi uczniami, z którymi stosunki ma bardzo dobre i którzy go wyjątkowo cenią. Kieruje on ich ideami naukowymi, daje tematy prac, odważnie je publikuje i troszczy się o wszystko, nawet o sytuację materialną swoich uczniów"35. Wiele życzliwości okazywał swoim uczniom nie tylko Sierpiński, lecz tak$\dot{z}$ e Stefan Mazurkiewicz ${ }^{36}$. Doceniając sukces szkoły i „Fundamenta Mathematicae", Łuzin i we wspomnianym liście, i w rozmowach z Sierpińskim wskazywał jednocześnie na niebezpieczeństwo, które kryje się w uprawianiu głównie teorii mnogości i dziedzin $z$ nia związanych - zdominowanie rodzimej matematyki. Przytaczal również odpowiedź Sierpińskiego: „Tak, kryje się w tym poważne niebezpieczeństwo, lecz większym niż dominacja jednej tendencji jest brak jakiejkolwiek [...]. Co się tyczy naszej ograniczoności, to mam nadzieję, że zmniejszy się ona, aż wreszcie zniknie" ${ }^{\prime 3}$. Rzeczywiście $z$ czasem krąg zainteresowań warszawskich matematyków się poszerzał.

Jeśli chodzi o sposób współpracy, to przykład ze swych nauczycieli brali też wychowankowie szkoły, w niemal całym zespole warszawskich matematyków panowała atmosfera twórczego współdziałania i życzliwości, o czym świadczy chociażby duża liczba wspólnych prac ukazujących się np. w „Fundamenta Mathematicae”. Najstarsi z wychowanków szkoły szybko właczali się też w budowanie jej pozycji, nie tylko przez prace naukowe. Na przykład Kazimierz Kuratowski od początku wspierał swoich profesorów w redagowaniu „Fundamenta Mathematicae”, a gdy w 1922 r. został docentem na UW, zaczął wyszukiwać utalentowanych studentów, otaczać ich opieką i wdrażać w pracę naukową grupy, dotyczyło to m.in. Edwarda Szpilrajna i Kazimierza Zarankiewi$\mathrm{cza}^{38}$. Spośród innych członków szkoły warszawskiej, oprócz Kuratowskiego, również Alfred Tarski natrafił na wielki talent matematyczny w osobie Andrzeja Mostowskiego. Także Aleksander Rajchman i Stanisław Saks mieli znaczacy wpływ na młodych wychowanków szkoły ${ }^{39}$.

35 N.N. Łuzin, Letters à Arnaund Denjoy, oprac. P. Dugac, „Archives Internationales d'Histoire des Sciences" 1977, t. XXVII, s. 203; id e m, List do Arnaunda Denjoy, „Wiadomości Matematyczne” 1983, t. XXV, z. 1, s. 67.

${ }^{36}$ K. Kura tow ski, Notatki do autobiografii..., s. 78.

${ }^{37}$ N.N. Luzin, Letters..., s. 204; id e m, List do Arnaunda Denjoy..., s. 67.

${ }^{38}$ Umiejętność dostrzegania uzdolnionych młodych ludzi cechowała go przez całe życie, również jako profesora Politechniki Lwowskiej, którym był w latach 1927-1933. Odkrył wtedy talent Stanisława Ulama. S. Ulam, Przygody matematyka, Warszawa 1996, s. 56, 57.

${ }^{39}$ A. Burdman Feferman, S. Feferman, Alfred Tarski. Życie i logika, Warszawa 2009, s. 129; A. Zyg mu nd, Aleksander Rajchman (1890-1940), „Wia- 
W Warszawie intensywnie rozwijała się również logika matematyczna. Szkoła stworzona przez Jana Łukasiewicza, Stanisława Leśniewskiego i najstarszego $z$ ich wychowanków Alfreda Tarskiego już na początku lat trzydziestych zyskała uznanie w świecie naukowym. Grupę tworzyli również: Adolf Lindenbaum, jego późniejsza żona - Janina Hosiasson, Zygmunt Kobrzyński, Stanisław Jaśkowski, Moses Presburg, Mordechaj Wajsberg, Bolesław Sobociński, Jerzy Słupecki i Andrzej Mostowski. Duży wpływ na szybki rozwój szkoły miała bardzo przychylna dla logików atmosfera panująca na Uniwersytecie. W innych ośrodkach takich warunków brakowało, natomiast dość powszechne było niedocenianie tej nowo tworzącej się dziedziny matematyki ${ }^{40}$.

Warszawska szkoła matematyczna stworzona przez naukowców, którzy pracowali wcześniej na Uniwersytecie we Lwowie, od początku wspierała nowo tworzaca się grupę skupioną wokół Hugona Steinhausa i Stefana Banacha. Ta, wraz ze wzrostem pozycji naukowej Steinhausa i Banacha, szybko się powiększała. Jak wspomniano, niebagatelna rolę i tu odegrało czasopismo „Fundamenta Mathematicae", w kręgu jego zainteresowań leżały bowiem także dziedziny, którymi zajmowała się grupa lwowska: analiza funkcjonalna, teoria miary, teoria szeregów, rachunek prawdopodobieństwa. Niewątpliwie znacząco przyczyniło się do szybkiego rozwoju szkoły lwowskiej.

Oprócz założycieli - Banacha i Steinhausa - szkołę lwowską tworzyli: Stefan Kaczmarz, Juliusz Schauder, Władysław Nikliborc, a $z$ urodzonych po 1900 r. Herman Auerbach, Władysław Orlicz, Zygmunt Birbaum, Stanisław Mazur, Józef Schreier, Stanisław Ulam, Marek Kac, Meier Eidelheit, Menahem Wojdysławski. Ważnym członkiem grupy stał się też Kazimierz Kuratowski. Po przeniesieniu się do Lwowa w 1927 r. bardzo łatwo zintegrował się z nowym zespołem, a okres lwowski - jak wspomina - był najbardziej twórczy w jego życiu naukowym. W integracji $z$ grupa pomogła mu niewątpliwie panujaca w niej przyjacielska atmosfera i tolerancja widoczna w całym tamtejszym środowisku matematycznym. Także to, że przyjaźnie i współpraca zawiązywały się bez względu na pochodzenie, wyznanie, poglądy polityczne. Nie bez znaczenia była te $\dot{z}-$ jak

domości Matematyczne" 1987, t. XXVII, z. 2, s. 220, 221; ide m, Stanisław Saks (1897-1942), „Wiadomości Matematyczne” 1982, t. XXVI, z. 2, s. 148, 149.

${ }^{40} \mathrm{~J}$. Woleń s ki, Essays in the history of logic and logical philosophy, Kraków 1999, s. 80-83; R. J a d czak, Mistrz i jego uczniowie, Warszawa 1997, s. 108, 109, 112. 
wspomina - aura niezwykłości, która już wówczas otaczała środowisko lwowskich matematyków ${ }^{41}$.

Rok 1927 przyniósł również wydarzenie ważne dla całego lwowskiego środowiska matematycznego - odbył się wówczas I Polski Zjazd Matematyczny. Goszczono na nim nie tylko polskich matematyków, lecz także grupę zagranicznych uczonych, m.in. reprezentującego wówczas Niemcy Johna von Neumanna, który później ściśle współpracował $z$ polskimi matematykami, zapraszał ich do ośrodków, w których pracował ${ }^{42}$, przyjeżdżał do Polski, pisywał do polskich czasopism (zamieścił np. pięć prac w „Fundamenta Mathematicae”). Organizacja zjazdu we Lwowie niewatpliwe była wyróżnieniem dla tamtejszych matematyków. Okazała się także istotna dla rozwoju tamtejszej szkoły matematycznej. Ze wspomnień Steinhausa wynika, że docenienie środowiska i udany zjazd wpłynęły na pojawienie się u niego pomysłu założenia własnego międzynarodowego czasopisma o jeszcze węższej specjalizacji niż „Fundamenta Mathematicae”, obejmujacej analizę funkcjonalna i dziedziny pokrewne ${ }^{43}$. Steinhaus zrealizował ten pomysł wspólnie $z$ Banachem jako współredaktorem. „Studia Mathematica” - bo tak nazwano nowe czasopismo - zaczęły się ukazywać w 1929 r. Periodyk w krótkim czasie stał się jednym $z$ najważniejszych miejsc tworzenia się nowoczesnej analizy funkcjonalnej. W sumie w dziewięciu tomach znalazło się 157 prac naukowych. Wśród ogólnej liczby 56 autorów było 27 Polaków i 29 osób z zagranicy (najwięcej ze Stanów Zjednoczonych i ZSRR). Spośród uczonych zagranicznych największa liczbę prac zamieścili: Aurel Wintner - USA (3), Jovan Karamata - Jugosławia (2) i Simon Sidon - Węgry $(2)^{44}$.

Czasopismo promowano w podobny sposób jak „Fundamenta Mathematicae”. Wielu autorów tekstów zamieszczonych w obu periodykach pochodziło $z$ innych niż wymienione państw. Ich zainteresowanie było zapewne $\mathrm{w}$ dużym stopniu wynikiem rozpropagowywania czasopism w czasie różnych podróży naukowych, kongresów międzynarodowych, ponieważ w okresie międzywojennym polscy matematycy często wyjeżdżali za granicę w celach naukowych i gościli na wielu uczelniach.

${ }^{41}$ K. Kuratow ski, Notatki do autobiografii..., s. 89, 90, 93-96.

${ }^{42}$ John von Neumann urodził się w Budapeszcie. W 1926 r. zamieszkał na stałe w Niemczech, a w 1930 r. w USA (profesor Uniwersytetu w Princeton).

${ }^{43} \mathrm{H}$. S tein haus, Wspomnienia i zapiski..., s. 114.

${ }^{44}$ M. Przeniosło, International mathematical journals..., s. 22, 23. 
Wyjazdy naukowe w dużym stopniu wiązały się z zaproszeniami wystosowywanymi przez zagraniczne uczelnie. Wraz ze wzrostem renomy polskich szkół matematycznych coraz więcej jej przedstawicieli chciano bowiem gościć w różnych ośrodkach zagranicznych. Zapraszano ich zarówno na krótkie pobyty, jak i całe cykle wykładów ${ }^{45}$. Uznanie dla wyników naukowych szczególnie często okazywano w ten sposób Wacławowi Sierpińskiemu, a on niemal nigdy nie odmawiał. Wykładał na Uniwersytetach w Paryżu, Strasburgu, Brukseli, Cluj, Princeton, Rzymie, Budapeszcie, Szegedzie, Genewie i Lozannie ${ }^{46}$. Zaproszenia do wygłoszenia wykładów za granica chętnie przyjmowali także wychowankowie obu szkół, wspomniano o podróży do USA Kazimierza Kuratowskiego w 1936 r. Za oceanem przebywał prawie pół roku, najpierw na Uniwersytecie w Princeton i w prestiżowym Institute for Advanced Study, gdzie wygłosił 12 wykładów na temat Theory of Borel, analytic and projective sets oraz General theory of function. Następnie gościł w Filadelfii na Uniwersytecie Stanu Pensylwania oraz w Bryn Mawr i Swarthmore College (mówił na temat: $n$-dimensional local connectedness), w Cambridge na Uniwersytecie Harvarda (Some properties of Borel and projective sets), w Providence na Uniwersytecie Browna (Transfinite induction and projective sets), w Nowym Jorku na Uniwersytecie Columbia (Some applications of logical notations to the theory of sets and of functions). W Nowym Jorku przedstawił także odczyt w Amerykańskim Towarzystwie Matematycznym (A topological method of proving existence theorems). Kolejne wykłady dotyczace topologii, teorii mnogości, teorii funkcji oraz logiki matematycznej wygłosił w Charlottesville na Uniwersytecie Stanu Wirginia, w Chapel Hill na Uniwersytecie Stanu Nowa Karolina, w Durham na Uniwersytecie Duka, w Ann Arbor na Uniwersytecie Stanu Michigan oraz na uniwersytetach $\mathrm{w}$ Buffalo i kanadyjskim Toronto. Jego prezentacje odnosiły się nie tylko do osobistych wyników, lecz także do dokonań całej polskiej szkoły matematycznej w tych dziedzinach ${ }^{47}$.

${ }^{45}$ Szerzej na temat naukowych podróży zagranicznych polskich matematyków por. eadem, Zagraniczne wyjazdy naukowe polskich matematyków $w$ okresie międzywojennym, „Analecta” 2009, t. XVIII, nr 1-2, s. 311-330.

46 Teczka osobowa W. Sierpińskiego, AAN, MWRiOP, sygn. 5618, k. 63-65, $182,188$.

47 Teczka osobowa K. Kuratowskiego, AAN, MWRiOP, sygn. 3841, k. 245-247, 251-254. 
W czasie podobnych wyjazdów matematycy podtrzymywali dotychczasowe kontakty naukowe, nawiązywali również nowe. W 1921 r. w naukową podróż po ośrodkach niemieckich wybrał się np. Hugo Steinhaus. Chciał zarówno odnowić dawne kontakty naukowe w Getyndze, jak i poszukać nowych, odwiedził w tym celu Berlin, Hamburg i Lipsk. Szczególnie owocna okazała się wizyta w Lipsku u prof. Leona Lichtensteina, $z$ nawiązanych kontaktów korzystali potem młodzi polscy matematycy. W 1925 r. Steinhaus wybrał się $z$ kolei na trzy miesiące do Paryża, tym razem ze Stefanem Banachem. Do Francji pojechali (odwiedzili też Strasburg) na zaproszenie tamtejszych matematyków: Henriego Lebesgue'a, Jacques'a Hadamarda, Paula Montela i Maurica Frécheta (był wówczas profesorem Uniwersytetu w Strasburgu ${ }^{48}$ i jednym $z$ pierwszych zagranicznych matematyków, którzy dostrzegli wage prac Banacha) ${ }^{49}$.

Spośród wspomnianych ośrodków niemieckich Berlin był często obierany jako cel podróży przez naukowców zainteresowanych zastosowaniami matematyki. Odwiedzano przede wszystkim Instytut Matematyki Stosowanej funkcjonujacy przy tamtejszym uniwersytecie, który był bardzo znana, nowoczesna jednostką badawczą. Nie bez znaczenia było też to, że jego dyrektor, prof. Richard von Mises, miał wiele życzliwości dla polskich matematyków. W $1931 \mathrm{r}$. Instytut stał się celem podróży naukowej młodego warszawskiego matematyka Kazimierza Zarankiewicza, który wyjechał dzięki stypendium Funduszu Kultury Narodowej (dalej: FKN). Współpraca $z$ prof. Misesem i $z$ pracującym również w Instytucie, a pochodzącym z Częstochowy, Stefanem Bergmanem oraz prof. Georgiem Hamelem $z$ Politechniki w podberlińskim Charlottenburgu spowodowała głębsze zainteresowanie się Zarankiewicza zastosowaniami matematyki. To $z$ kolei zaowocowało opracowaniem w kolejnych latach ważnej metody odwzorowań konformicznych i jej zastosowań do różnych zagadnień fizycznych ${ }^{50}$. $Z$ kolei Karol Borsuk, który również gościł w Berlinie, stale współpracował $z$ redakcją wychodzącego tam periodyku „Jahrbuch über die Fortschritte der Mathematik” zamieszczajacego recenzje prac matematycznych ${ }^{51}$.

${ }^{48}$ W Strasburgu pracował do 1927 r., później w Paryżu.

${ }^{49} \mathrm{H}$. Stein hau s, Wspomnienia i zapiski..., s. 110, 115.

50 Teczka osobowa K. Zarankiewicza, AAN, MWRiOP, sygn. 6801, k. 27, 28,45 .

${ }^{51}$ Teczka osobowa K. Borsuka, AAN, MWRiOP, sygn. 1817, k. 4, 54, 55. 
Duża grupa polskich matematyków - topologów i logików - wyjeżdżała na Uniwersytet w Wiedniu, zarówno by wygłaszać wykłady, jak i współpracować $z$ seminarium topologicznym Karla Mengera (on też przyjeżdżał do Polski) i tzw. Kołem Wiedeńskim - znana, elitarna grupą logików i filozofów. W 1930 r. Wiedeń stał się celem podróży naukowej Alfreda Tarskiego (gościł tam jeszcze kilkukrotnie) i Bronisława Knastera, w 1931 r. Antoniego Zygmunda i Kazimierza Zarankiewicza, w 1932 r. Karola Borsuka, w 1934 r. Jana Łukasiewicza i Stanisław Ulam ${ }^{52}$.

Młodzi polscy matematycy często korzystali ze stypendiów umożliwiających kilkumiesięczne pobyty w zagranicznych ośrodkach akademickich. Nierzadko wybierali te uczelnie, na których ich mistrzowie mieli kontakty naukowe. Spośród ośrodków europejskich dotyczyło to np. Paryża, Lipska i Cambridge, a za oceanem Princeton i Providence. W Paryżu szczególnie dobre kontakty polscy profesorowie mieli z Henrim Lebesgue'em, Mauricem Fréchetem, Paulem Montelem i Arnaudem Denjoy (wszyscy czterej odwiedzali też Polskę). Na Sorbonie przebywało kilkunastu młodych polskich matematyków, m.in. Antoni Zygmund, Juliusz Schauder, Kazimierz Zarankiewicz, Stanisław Ulam. Schauder podczas pobytu w Paryżu w 1933 r. rozpoczął współpracę $z$ młodym matematykiem Jeanem Leray, która potem zaowocowała prestiżową międzynarodowa nagrodą Metaxasa, przyznana im wspólnie w 1938 r. ${ }^{53} \mathrm{Z}$ kolei Ulam do Paryża udał się w 1934 r., by w Instytucie im. Poincarégo poznać i przedyskutować pewne pomysły dotyczace teorii grup z szacownym profesorem Élie Cartanem. Spotkanie było możliwe dzięki listowi polecającemu od Hugona Steinhausa. W czasie tego pobytu Ulam uczęszczał także na wykłady i seminaria na Sorbonie, a ponieważ niektóre jego wyniki były znane w tym środowisku, zaproponowano mu wygłoszenie kilku wykładów ${ }^{54}$. W tym samym roku Kazimierz Zarankiewicz podczas pobytu w Paryżu wygłosił odczyt we Francuskim Towarzystwie Matematycznym na temat, wspomnianej, opracowanej przez niego metody odwzorowań konformicznych, którą prezentował też na zaproszenie innych ośrodków naukowych, m.in. w Cambridge ${ }^{55}$.

${ }^{52}$ M. Przeniosło, Zagraniczne wyjazdy naukowe..., s. 319, 322, 326.

53 Akta J. Schaudera, Archiwum Oddziału Gdańskiego Instytutu Matematycznego Polskiej Akademii Nauk w Sopocie [dalej: APAN w Sopocie], Zbiór Juliusza Schaudera [dalej: ZJS], sygn. Sch-II-1b, Sch-III-3.

${ }^{54}$ S. Ulam, Przygody matematyka..., s. 87, 88.

55 Teczka osobowa K. Zarankiewicza, AAN, MWRiOP, sygn. 6801, k. 49. 
Z kolei na Uniwersytecie w Lipsku pracował, jak wspomniano, prof. Leon Lichtenstein, który pochodził $z$ Warszawy, przyjaźnił się z Hugonem Steinhausem i chętnie wspierał młodych polskich matematyków. Przebywali tam m.in. Władysław Nikliborc i Juliusz Schauder. W roku akademickim 1928/1929 Nikliborc otrzymał stypendium FKN na pobyt w Niemczech i we Francji. Trafił wówczas również do Lipska i znalazł tam odpowiednie środowisko do rozwoju swoich zainteresowań matematycznych. Wyjeżdżał tam jeszcze kilkukrotnie, m.in. w 1930/1931 dzięki stypendium Fundacji Rockefellera. Efektem tych podróży były m.in. publikacje naukowe w czasopiśmie „Mathematische Zeitschrift”56. Stypendium na pobyt na Uniwersytecie w Lipsku w roku akademickim 1932/1933 przyznano także Juliuszowi Schauderowi (otrzymał je z Fundacji Rockefellera). Był tam już wcześniej, w 1930 r., podróżując na własny koszt. Współpraca $z$ Lichtensteinem zdecydowała o zajęciu się przez niego równaniami różniczkowymi, w których potem odniósł znaczace sukcesy ${ }^{57}$.

Hugo Steinhaus znał się także $z$ prof. Godfreyem H. Hardym $z$ Uniwersytetu w Cambridge. By współpracować $z$ Hardym i grupa jego uczniów, na tę uczelnię wybrało się kilku polskich matematyków, byli wśród nich m.in. Antoni Zygmund, Kazimierz Zarankiewicz i Stanisław Ulam. Zygmund wyniósł $z$ pobytu w Cambridge w roku akademickim 1929/1930 szczególne korzyści naukowe. Współpracując $z$ tamtejszą szkoła, zwrócił uwage na wielki talent młodego matematyka Raymonda Paley'a. Zapoczątkowało to cykl ich wspólnych prac na temat probabilistycznych szeregów Fouriera, pierwsza $z$ nich ukazała się w 1930 r. we lwowskim czasopiśmie „Studia Mathematica”. Podsumowaniem współpracy była znana książka Zygmunda Trigonometric series, która została przygotowana już tylko przez niego po tragicznej śmierci Paley'a ${ }^{58}$.

Do Stanów Zjednoczonych młodzi polscy matematycy wyjeżdżali m.in. na zaproszenie prof. Johna von Neumanna pracującego w Institute for Advanced Study działajaccego w ramach Uniwersytetu

${ }^{56}$ Teczka osobowa W. Nikliborca, LPAO, UJK, f. 26, op. 5, spr. 1355, k. 4, 7, 11; Teczka osobowa W. Nikliborca, AAN, MWRiOP, sygn. 4593, k. 23, 30; D. Przeworska-Rolewicz, Leon Lichtenstein, [w:] European mathematics in the last century, red. W. Więsław, Wrocław 2005, s. 100-106.

${ }^{57}$ Akta J. Schaudera, APAN w Sopocie, ZJS, sygn. Sch-II-1b, Sch-III-3.

58 Teczka osobowa K. Zarankiewicza, AAN, MWRiOP, sygn. 6801, k. 49; Teczka osobowa A. Zygmunda, ibidem, sygn. 6938, k. 9; S. Ulam, Przygody matematyka..., s. 88-92. 
w Princeton. Na przykład w 1935 r. pojechał tam na roczne stypendium Stanisław Ulam, ale pozostał na stałe ${ }^{59}$. $Z$ kolei na Uniwersytecie Browna w Providence pracował prof. Jacob D. Tamarkin, który chętnie gościł i wspierał polskich matematyków. W 1933 r. przebywał tam np. Stanisław Saks. Efektem jego wyjazdu była seria publikacji w amerykańskich periodykach, m.in. w bardzo prestiżowym „Annales of Mathematics"60. Tamarkin opublikował także kilka bardzo pochlebnych recenzji książek napisanych przez Polaków ${ }^{61}$. Oprócz Ulama jeszcze kilku innych wychowanków polskich szkół matematycznych pod koniec lat trzydziestych wyjechało na stałe do USA: warszawskiej - Samuel Eilenberg, Alfred Tarski i Antoni Zygmund $^{62}$, lwowskiej - Zygmunt Birnbaum i Marek Kac. Wszyscy wymienieni zrobili tam znaczącą karierę naukową.

Kontakty $z$ matematykami $z$ krajów Europy Środkowo-Wschodniej nie były uwieńczone zbyt częstymi wzajemnymi wizytami, rozwój matematyki w tych państwach nie był tak dynamiczny, jak w Polsce. W 1929 r. w Warszawie zorganizowano Kongres Matematyków Krajów Słowiańskich, zjawili się przedstawiciele wszystkich państw poza Rosjanami. W 1934 r. kolejny taki zjazd odbył się w Pradze, uczestniczyli w nim również Polacy. Gościli też w tym 1929 r. i 1932 r. na Uniwersytecie w Cluj w związu I i II Zjazdem Matematyków Rumuńskich. Kontakty $z$ tą uczelnią były dość ożywione, pracował tam prof. Petre Sergescu, który nierzadko bywał w Polsce $z$ powodów naukowych (m.in. na organizowanych tu zjazdach), jak i osobistych (pochodziła stąd jego żona). $Z$ wykładami wyjeżdżał tam $z$ kolei Sierpiński. Odwiedzał on w takim celu także uniwersytet $\mathrm{w}$ rumuńskich Jassach i w Szegedzie na Węgrzech.

${ }^{59}$ N. Macrae, John von Neumann. The scientific genius who pioneered the modern computer, game theory, nuclear deterrence, and much more, Providence 1999, s. 170; S. Ula m, Przygody matematyka..., s. 95, 112.

${ }^{60}$ Teczka osobowa S. Saksa, AAN, MWRiOP, sygn. 5510, k. 62, 84, 88; H. Stein haus, Wspomnienia i zapiski..., s. 154.

61 J.T. Tamarkin (rec.), Antoni Zygmund, Trygonometrical series, Warsaw and Lviv 1935, „Bulletin of the American Mathematical Society” 1936, t. XLII, s. 11-13; id em, Stanislaw Saks, Théorie de l'intégrale, Warsaw 1933, „Bulletin of the American Mathematical Society" 1934, t. XL, s. 16-18; idem, Stefan Banach, Théorie des operations linéaires, Warsaw 1932, ibidem, s. 13-16; id e m, Stefan Kaczmarz, Hugo Steinhaus, Theorie der Orthogonalreihen, Warsaw and Lviv 1935, „Bulletin of the American Mathematical Society” 1938, t. XLIV, s. $20-21$.

${ }^{62}$ Od 1930 r. był profesorem Uniwersytetu Stefana Batorego w Wilnie, z Polski udało mu się wyjechać już po wybuchu II wojny światowej. 
$Z$ kolei Bronisław Knaster gościł $z$ wykładami w Pradze i Brnie, a Jan Łukasiewicz w pierwszym $z$ wymienionych miast. Matematycy $z$ krajów Europy Środkowo-Wschodniej pisywali też do „Fundamenta Mathematicae” i „Studia Mathematica”. W warszawskim periodyku kilka tekstów zamieścił czeski matematyk Wojtech Jarnik, a we lwowskim Jovan Karamata (Jugosławia) i Simon Sidon (Węgry).

Zarówno młodzi, jak i utytułowani matematycy chętnie wybierali się na duże zjazdy i konferencje zagraniczne, dawały one bowiem szansę promowania swoich wyników w szerokim gronie. Spośród polskich matematyków reprezentacja naukowców $z$ Warszawy i ze Lwowa zawsze była najliczniejsza. Po rozwinięciu się tamtejszych szkół w dużych grupach wyjeżdżano na międzynarodowe kongresy matematyczne odbywające się co cztery lata w różnych krajach. Na kongresie w Bolonii w 1928 r. wśród ponad 800 matematyków z 40 państw z referatami pojechało 11 matematyków z Warszawy, pięciu ze Lwowa i kilku z Krakowa, Wilna i Poznania. Na jednego z wiceprzewodniczacych zjazdu wybrano Wacława Sierpińskiego. W 1932 r. do Zurychu pojechało 14 Polaków, tu wiceprzewodniczącym był najbardziej znany krakowski matematyk - prof. Stanisław Zaremba $z$ UJ. Na ostatni przed II wojna światowa kongres w Oslo w 1936 r. wybrało się 17 polskich matematyków, do wygłoszenia jednego $z$ prestiżowych wykładów plenarnych zaproszono Stefana Banacha ${ }^{63}$.

Oprócz zjazdów ogólnomatematycznych w okresie międzywojennym zaczęto urządzać konferencje specjalistyczne, na które organizatorzy zapraszali najbardziej znanych matematyków zajmujących się danym działem matematyki. Takie zjazdy zaczęli organizować topolodzy, logicy, naukowcy zajmujący się geometrią, rachunkiem prawdopodobieństwa, podstawami matematyki i jej zastosowaniami. Na niemal wszystkie, organizowane w całej Europie i USA, zapraszano Polaków. Zapraszano ich również do krajów, których stosunki polityczne $z$ Polską były trudne. Grupa warszawskich topologów gościła np. w 1935 r. na Międzynarodowej Konferencji Topologicznej w Moskwie, która zorganizowano $z$ dużym rozmachem: zaproszono w sumie 30 gości zagranicznych. Mimo napiętych stosunków z ZSRR polskie władze nigdy nie utrudniały współpracy naukowej $z$ rosyjskimi matematykami. Wspomniana konferencja była jednak ostatnim takim kontaktem $z$ rosyjska

${ }^{63}$ Szerzej por. M. Przeniosło, Zagraniczne wyjazdy naukowe..., s. 323-326. 
matematyka - decyzją władz ZSRR współpraca naukowa z matematykami zagranicznymi została wkrótce zerwana ${ }^{64}$.

Wyjazdy naukowe niewatpliwie przynosiły uczonym indywidualne sukcesy, międzynarodowe kongresy pozwalały warszawskim i lwowskim matematykom na zaprezentowanie się również jako grupa. Za pośrednictwem podróżujących zyskiwano także nowych współpracowników. „Fundamenta Mathematicae” i „Studia Mathematice" zasilało wielu nowych autorów $z$ całego świata, co podnosiło ich range i pomagało w zdobywaniu renomy przez szkoły.

Do Warszawy i Lwowa przyjeżdżało też coraz więcej zagranicznych uczonych, zarówno znanych profesorów (o kilkunastu wspomniano), jak i stypendystów, by poznawać uczelnie, współpracować $z$ pracującymi na nich matematykami, wygłaszać wykłady, uczestniczyć w konferencjach. Zagranicznym matematykom czasem wręczano doktoraty honorowe polskich uczelni i nawet ci najbardziej znani traktowali to jako zaszczyt, np. na UW w 1930 r. goszczono w związku $z$ tym Emila Borela, w 1935 r. Luisa de Broglie i Paula Montela, a na UJK w 1938 r. - Henriego Lebesgue'a ${ }^{65}$.

Do Lwowa przyciagał zagranicznych matematyków nie tylko sukces tamtejszej szkoły, lecz także aura niezwykłości, która otaczała sposób współpracy tamtejszych matematyków. Grupa spędzała wiele godzin na dyskusjach o matematyce - formułowaniu nowych problemów i udowadnianiu ich, nierzadko odbywano wręcz wielogodzinne maratony wytężonego myślenia. Spotkania te miały atmosferę, która Stanisław Ulam nazwał unikalną. Często odbywano te specyficzne seminaria (dotyczyło to szczególnie Stefana Banacha i jego najbliższych współpracowników) w miejscach równie nietypowych. Dyskusje nierzadko toczono bowiem nie na uniwersytecie, a we lwowskich kawiarniach i gospodach, z miejscowym jedzeniem, litrami kawy i trunków. Na początku lat trzydziestych na miejsce spotkań wybrano Café Roma, potem przeniesiono się do innej kawiarni, której nazwa - Szkocka dziś jest niemal symboliczna. Marmurowe kawiarniane stoliki wykorzystywano jako tablice do pisania ołówkiem chemicznym, co sprawiło, że wiele wyników się nie zachowało. Nikt nie zanotował ich bowiem na kartce, a że były to wytwory zbiorowego myślenia, nikt też nie potrafił ich odtworzyć. W związku $z$ tym żona Banacha kupiła w pewnym momencie gruby zeszyt w twardej marmurkowej okładce, by wreszcie bywalcy

${ }^{64}$ I d e m, Kontakty naukowe polskich i rosyjskich matematyków..., s. 125-127.

${ }^{65}$ K. Ku ra tow s ki, Pół wieku matematyki polskiej..., s. 64-69. 
Kawiarni Szkockiej zaczęli spisywać swe pomysły w trwalszej formie. Matematycy wykorzystali notatnik w nieco inny sposób - do stawiania nowych problemów jako wyzwań dla innych naukowców. Był on przechowywany w kawiarni i udostępniany każdemu matematykowi. Nowe problemy zapisywano na pierwszych stronicach kolejnych kartek, tak żeby rozwiązanie można było kiedyś wpisać na odwrotnej wolnej stronie ${ }^{66}$. W ten sposób powstała Księga Szkocka, która stała się symbolem lwowskiej szkoły matematycznej. Oryginalna Księga Szkocka pozostaje w posiadaniu rodziny Stefana Banacha ${ }^{67}$ (kopię można znaleźć np. na internetowych stronach Uniwersytetu im. Adama Mickiewicza w Poznaniu ${ }^{68}$ ).

Pierwsze wpisane w księdze zagadnienie pochodzi z 7 lipca $1935 \mathrm{r}$. i zostało zanotowane przez Stefana Banacha, ostatnie, datowane na 3 maja 1941 r., wpisał Hugo Steinhaus. Lektura księgi robi równie duże wrażenie jak historia związana $z$ jej powstaniem. Znalazły w niej bowiem odbicie zarówno osiagnięcia naukowe, jak i atmosfera współpracy międzywojennych polskich matematyków. Widnieja w niej wpisy wszystkich członków grupy lwowskiej, wielu warszawskiej i znanych matematyków $z$ różnych krajów, którzy odwiedzili Lwów, chociażby Maurica Frécheta, Johna von Neumanna. Karty księgi oddają też wymownie specyfikę współpracy lwowskich matematyków, za rozwiązanie postawionych problemów często obiecywano bowiem różnorodne nagrody (np. „małe jasne”, „flaszka koniaku”, „mała czarna”, „10 dkg kawioru”). Czasem propozycje gratyfikacji były jeszcze zabawniejsze, np. Stanisław Mazur zaoferował, dziś już anegdotyczną, żywą gęś (wpis z 6 listopada 1936 r.). Problem, za który Mazur obiecał tak oryginalna nagrodę, czekał na udokumentowane rozwiąanie bardzo długo. Trzydzieści sześć lat później, 12 grudnia 1972 r., na uroczystym posiedzeniu Polskiego Towarzystwa Matematycznego w Warszawie Stanisław Mazur wręczył obiecana żywą gęś. Otrzymał ją Per Enflö - profesor amerykańskiego Uniwersytetu Stanu Kalifornia w Berkeley, który osobiście stawił się po odbiór słynnej już wówczas nagrody ${ }^{69}$, co niewątpliwie świadczy o renomie szkoły - jej legenda i dokonania przetrwały

${ }^{66}$ S. Ulam, Przygody matematyka..., s. 64-66, 79, 80; idem, An anecdotal history of the Scottish Book, [w:] The Scottish Book: Mathematics from Scottish Café, ed. D. Mauldin, Boston 1981, s. 3-15.

${ }^{67}$ R. Kałuża, Stefan Banach..., s. 112.

${ }^{68}$ http://kielich.amu.edu.pl/Stefan_Banach/archiwalia.html.

${ }^{69}$ K. Kuratow ski, Pół wieku matematyki polskiej..., s. 49-53. 
znacznie dłużej niż ona sama (lwowscy matematycy mogli wspólnie pracować do 1941 r., do wkroczenia Niemców do miasta, choć polski uniwersytet przestał tam istnieć wkrótce po zajęciu Lwowa przez Rosjan w 1939 r. $^{70}$ ).

Jeśli chodzi o wkład naukowców obu szkół w rozwój matematyki, to najbardziej znaczacy i trwały był on w przypadku teorii mnogości, topologii, analizy funkcjonalnej i logiki matematycznej. Szczegółowy opis osiągnięć wykracza poza ramy tego artykułu ${ }^{71}$, ale warto wymienić najważniejsze $z$ nich, szczególnie te do dziś kojarzone w literaturze światowej $z$ nazwiskami warszawskich i lwowskich matematyków. W teorii mnogości (zwanej też teorią zbiorów) matematycy $z$ całego świata zajmowali się m.in. dwoma ważnymi problemami - hipoteza continuum i aksjomatem wyboru. Spośród polskich matematyków najbardziej znaczace ustalenia na ich temat poczynili: Wacław Sierpiński, Alfred Tarski, Adolf Lindenbaum, Kazimierz Kuratowski i Stefan Banach. Na trwałe do matematyki weszło m.in. twierdzenie Lindenbauma-Tarskiego-Sierpińskiego wskazujące na związek obu wymienionych pojęć oraz lemat Kuratowskiego-Zorna zawierający jedna $z$ wersji tzw. zasad maksimum, które do dziśs odgrywaja istotna rolę w większości uprawianych dziedzin matematyki. Słynny stał się także paradoks Banacha-Tarskiego ${ }^{72}$ odkryty przez nich w 1924 r. jako konsekwencja aksjomatu wyboru i opublikowany w „Fundamenta Mathematicae”. Dziś jest on znany w wielu wersjach wynikajacych $z$ twierdzenia udowodnionego w oryginalnym tekście. Dość obrazowa jest np. wersja, że dowolnej wielkości kulę można podzielić na skończoną liczbę części, z których można następnie złożyć kulę dowolnej innej wielkości. Prowadzi bowiem do stwierdzenia, że ziarnko grochu może być podzielone na skończenie wiele części, z których można następnie złożyć kulę wielkości słońca. W ramach badań topologicznych najbardziej znaczace okazały się prace Kuratowskiego - odegrały one zasadnicza rolę w przeniesieniu wcześniejszych teorii na ogólny przypadek przestrzeni abstrakcyjnych nazwanych później przestrzeniami polskimi. Osiagnięcia na skalę międzynarodową warszawscy uczeni odnotowali

\footnotetext{
${ }^{70}$ Szkoła warszawska szybko odrodziła się po II wojnie światowej, choć część jej dawnych członków wojny nie przeżyła lub pozostała na emigracji.

${ }^{71} \mathrm{Na}$ ten temat por. M. Przeniosło, Matematycy polscy..., s. 203-217.

${ }^{72}$ Paradoksowi temu poświęcono wiele prac, w latach osiemdziesiatych badania nad nim zebrał Stanley Wagon w książce: The Banach-Tarski Paradox, Cambridge 1985.
} 
także w zakresie logiki. Największym z nich było odkrycie przez Jana Łukasiewicza logik wielowartościowych i badania ich dotyczace, które były prowadzone przez niego samego oraz przez Jerzego Słupeckiego, Bolesława Sobocińskiego i Mordechaja Wajsberga.

Ze szkołą lwowską kojarzona jest głównie analiza funkcjonalna, a $z$ nią nierozerwalnie wiąże się nazwisko Stefana Banacha. Sformułował on bowiem podstawy nowoczesnej analizy funkcjonalnej już w pracy doktorskiej opublikowanej w „Fundamenta Mathematicae” w 1922 r. Prowadził swoje rozważania, nie tak jak jego poprzednicy, którzy brali za punkt wyjścia konkretne przestrzenie funkcyjne, ale przyjmując aksjomatycznie pewne klasy obiektów, które określił jako B-przestrzenie; później matematycy nazwali je przestrzeniami Banacha (pierwszy uczynił to Maurice Fréchet). Inny typ tych przestrzeni badali Władysław Orlicz i Zygmunt Birmnbaum; później zostały one nazwane w literaturze światowej przestrzeniami Orlicza. $Z$ nazwiskami lwowskich matematyków do dziś są kojarzone także inne ustalenia $z$ zakresu analizy funkcjonalnej, m.in. twierdzenie Banacha, Banacha-Steinhausa, Hahna-Banacha, Gelfanda-Mazura. W dwóch ostatnich $z$ wymienionych twierdzeń pojawiły się także nazwiska matematyków zagranicznych, np. bardzo ważne twierdzenie o przedłużaniu funkcjonałów liniowych nazywane Hahna-Banacha zostało udowodnione niezależnie przez obu matematyków, Hahn uczynił to nieco wcześniej, Banach w ogólniejszej postaci. W tomie drugim „Studia Mathematica” Banach przyznal pierwszeństwo Hahnowi, ale matematycy wykorzystujący twierdzenie w kolejnych latach uhonorowali w jego nazwie obu twórców.

Polskie szkoły matematyczne - warszawska i lwowska - były znane i cenione w międzywojennym świecie naukowym, mimo krótkiego okresu ich istnienia. Źródeł tego fenomenu można upatrywać zarówno w zmianach ewolucyjnych - stopniowej budowie polskich ośrodków akademickich jeszcze w czasie zaborów oraz zyskiwaniu doświadczeń przez częste zagraniczne wyjazdy edukacyjne i naukowe - jak i w rewolucyjnych krokach podjętych przez twórców szkół. Wśród tych ostatnich decydujące znaczenie miało przekonanie o konieczności zmian w podejściu do organizowania pracy naukowej i skoncentrowanie się na nowo tworzących się dziedzinach matematyki. Konsekwencją było nie tylko stworzenie szkół, lecz także założenie ściśle specjalistycznych czasopism o charakterze międzynarodowym - „Fundamenta Mathematicae” w Warszawie i „Studia Mathematica" we Lwowie oraz szerokie otwarcie na współpracę 
naukową z zagranica. Obydwa te fakty budowały pozycję szkół. Czasopisma, dzięki ich wąskiej tematyce i trafnemu jej wyborowi, szybko zostały uznane przez matematyków zagranicznych zajmujacych się tymi kwestiami za dobre forum do prezentacji swoich badań. Stały się centrum rozwoju działów matematyki, którym były poświęcone. Ponieważ zajmowała się nimi duża grupa matematyków szkół warszawskiej i lwowskiej, kontakty z nimi również stały się bardzo pożądane. Skutkowało to coraz większą liczbą zagranicznych podróży naukowych, a te $z$ kolei czyniły polskie szkoły matematyczne coraz bardziej znanymi i przysparzały nowych autorów obu czasopismom. Oczywiście na rozwój szkół i ich kontaktów zagranicznych istotny wpływ miały znaczące wyniki naukowe ich przedstawicieli publikowane zarówno w „Fundamenta Mathematicae” i „Studia Mathematica”, jak i za granica. Wiele $z$ tych ustaleń weszło na trwałe do matematyki. Spuściznę taka stanowią też obydwa czasopisma, są one wydawane do dziś i cenione w świecie matematycznym.

\section{Bibliografia}

\section{Źródea ARChiwalne}

Archiwum Akt Nowych

Ministerstwo Wyznań Religijnych i Oświecenia Publicznego, sygn. 1817 (teczka osobowa - K. Borsuk), sygn. 3841 (K. Kuratowski), sygn. 4318 (S. Mazurkiewicz), sygn. 4593 (W. Nikliborc), sygn. 5435 (S. Ruziewicz), sygn. 5510 (S. Saks), sygn. 5618 (W. Sierpiński), sygn. 6801 (K. Zarankiewicz), sygn. 6938 (A. Zygmund).

Archiwum Główne Akt Dawnych

C.K. Ministerstwo Wyznań i Oświaty, sygn. 119u, podteczka Z. Janiszewskiego.

Archiwum Oddziału Gdańskiego Instytutu Matematycznego Polskiej Akademii Nauk w Sopocie

Zbiór Juliusza Schaudera, sygn. Sch-II-1b, Sch-III-3.

Archiwum Uniwersytetu Jagiellońskiego

Senat Akademicki II, sygn. 619, Teczka osobowa S. Zaremby.

Lwowskie Państwowe Archiwum Obwodowe we Lwowie

UJK, f. 26, op. 5, spr. 1355 (teczka osobowa - W. Nikliborc), spr. 2242 (Z. Janiszewski), spr. 2162 (H. Steinhaus). 


\section{$\dot{Z}_{\text {RÓDEA DRUKOWANE }}$}

Kuratowski K., Notatki do autobiografii, Warszawa 1981.

Kuratowski K., Pół wieku matematyki polskiej 1920-1970. Wspomnienia i relacje, Warszawa 1973.

Lebesgue H., A propos d'une nouvelle revue mathematique: 'Fundamenta Mathematicae', „Biulletin des Sciences Mathématiques” 1922, t. XLVI, s. 35-48.

Listy Wacława Sierpińskiego do Stanisława Ruziewicza, oprac. W. Więsław, „Wiadomości Matematyczne" 2004, t. XL, s. 139-167.

Listy Zygmunta Janiszewskiego, oprac. S. Kolankowski, Warszawa 1980.

Łuzin N.N., Letters à Arnaund Denjoy, oprac. P. Dugac, „Archives Internationales d'Histoire des Sciences" 1977, t. XXVII, s. 201-205.

Łuzin N.N., List do Arnaunda Denjoy, „Wiadomości Matematyczne” 1983, t. XXV, z. 1, s. 65-68.

Nowi profesorowie Uniwersytetu Warszawskiego, „Głos Narodu”, 31 X 1918, nr 245, s. 2.

Od Redakcji, „Nauka Polska” 1918, t. I, s. 8.

Sierpiński W., Matematyka polska $w$ czasie wojny i po wojnie, „Nauka Polska” 1947, t. XV, s. 90-96.

Sierpiński W., O polskiej szkole matematycznej, „Problemy” 1963, t. III, s. 147-149.

Steinhaus H., Między duchem a materia pośredniczy matematyka, oprac. J. Łukaszewicz, Warszawa 2000.

Steinhaus H., Wspomnienia i zapiski, Wrocław 2002.

Tamarkin J.D., 25 volumes of 'Fundamenta Mathematicae', „Bulletin of the American Mathematical Society" 1936, t. XLII, s. 300.

Tamarkin J.D. (rec.), Antoni Zygmund, Trygonometrical series, Warsaw and Lviv 1935, „Bulletin of the American Mathematical Society” 1936, t. XLII, s. 11-13.

Tamarkin J.D. (rec.), Stanislaw Saks, Théorie de l'intégrale, Warsaw 1933, „Bulletin of the American Mathematical Society" 1934, t. XL, s. 16-18.

Tamarkin J.D. (rec.), Stefan Banach, Théorie des operations linéaires, Warsaw 1932, „Bulletin of the American Mathematical Society” 1934, t. XL, s. 13-16.

Tamarkin J.D. (rec.), Stefan Kaczmarz, Hugo Steinhaus, Theorie der Orthogonalreihen, Warsaw and Lviv 1935, „Bulletin of the American Mathematical Society” 1938, t. XLIV, s. 20-21.

Twardowski K., Dzienniki, t. II, Torun 1997.

Ulam S., An anecdotal history of the Scottish Book, [w:] The Scottish Book: Mathematics from Scottish Café, ed. D. Mauldin, Boston 1981, s. 3-15.

Ulam S., Przygody matematyka, Warszawa 1996.

\section{OpRacowania}

Archibald R.C., Notes, „American Mathematical Monthly” 1921, t. XXVIII, s. 317. Burdman Feferman A., Feferman S., Alfred Tarski. Życie i logika, Warszawa 2009. Jadczak R., Mistrz i jego uczniowie, Warszawa 1997. 
Janiszewski Z., O potrzebach matematyki $w$ Polsce, „Nauka Polska” 1918, t. I, s. 11-18.

Kałuża R., Stefan Banach, Warszawa 1992.

Kordos M., Wykłady z historii matematyki, Warszawa 2010.

Macrae N., John von Neumann. The scientific genius who pioneered the modern computer, game theory, nuclear deterrence, and much more, Providence 1999.

Przeniosło M., International mathematical journals published in Poland between the Wars, „British Society for the History of Mathematics Bulletin” 2009, t. II, s. 20-26.

Przeniosło M., Kontakty naukowe polskich i rosyjskich matematyków $w$ dwudziestoleciu międzywojennym, „Studia z Dziejów Rosji i Europy Środkowo-Wschodniej” 2014, t. XLIX, s. 115-129.

Przeniosło M., Matematycy polscy w okresie międzywojennym, Kielce 2011.

Przeniosło M., Zagraniczne wyjazdy naukowe polskich matematyków $w$ okresie międzywojennym, „Analecta” 2009, t. XVIII, nr 1-2, s. 311-330.

Przeworska-Rolewicz D., Leon Lichtenstein, [w:] European mathematics in the last century, red. W. Więsław, Wrocław 2005, s. 100-106.

Reid C., Hilbert, New York 1970.

Stopka K., Banach A.K., Dybiec J., The history of the Jagiellonian University, Kraków 2000.

Wagon S., The Banach-Tarski Paradox, Cambridge 1985.

Woleński J., Essays in the history of logic and logical philosophy, Kraków 1999.

Zygmund A., Aleksander Rajchman (1890-1940), „Wiadomości Matematyczne” 1987, t. XXVII, z. 2, s. 219-231.

Zygmund A., Stanisław Saks (1897-1942), „Wiadomości Matematyczne” 1982 , t. XXVI, z. 2, s. 145-156.

Matgorzata Przenioseo

\section{Mathematical schools in interwar Poland and their relationships with international science}

IN the interwar period Polish mathematics created two thriving schools of mathematics - in Warsaw and in Lviv. In Warsaw the creators were: Wacław Sierpiński, Zygmunt Janiszewski, Stefan Mazurkiewicz, and in Lviv - Hugo Steinhaus and Stefan Banach. Although for many years Polish independent state did not exist as such and the conditions for the development of indigenous science were highly unfavourable, both schools quickly recorded significant achievements. This success came primarily due to their engagement into new trends in practicing mathematics, the creating of specialized journals - „Fundamenta Mathematicae” and „Studia Mathematica”, as well as many scientific trips. The journals achieved international success. They were quickly recognized by foreigners as an appropriate forum for the presentation of their own research. „Fundamenta Mathematicae” 
became one of the world's most important periodicals devoted to set theory, „Studia Mathematica" - functional analysis. With the increasing reputation of the Polish schools of mathematics, more and more of their representatives were invited by various foreign centres, both for short visits, as well as entire series of lectures. More and more foreign scholars, both well-known professors and scholarship holders, came to Warsaw and Lviv to work with the local mathematicians, deliver lectures and participate in conferences.

Keywords: history of science in the Second Republic of Poland, mathematicians, schools of mathematics. 